\title{
PENGUJIAN TEMBUS DIELEKTRIK MINYAK JARAK SEBAGAI ALTERNATIF PENGGANTI ISOLASI PADA MINYAK TRAFO
}

\author{
Purwiyanto $^{1}$, Galih Mustiko Aji ${ }^{2}$ \\ 1,2Jurusan Teknik Elektronika Politeknik Negeri Cilacap \\ E-mail: purwi_1979@yahoo.com, galihma@gmail.com
}

\begin{abstract}
To detach two or more conductors which have voltage in electrical power system, it is needed an insulation, then among conductors which have voltage do not occur electricity sputtering. Oil is an insulation material which much used to insulate and refrigerate the high voltage electrical tools. Oil insulator is an liquid insulation which derived from petroleum or crude oil which specifically processed until having characteristics as an insulator, but nowdays the world development demands for safe and eco-friendly products to decrease the effects of global warming. This condition opens the opportunity to use renewable energy which derived from vegeTabel oil. The breakdown voltage test of curcas liquid oil insulation materials at various electrode using transformator gulf oil as comparator, it aims to study insulation power of curcas oil towards the breakdown voltage with various temperature and gap spacing. Based on the result of the test, it shows that the breakdown voltage of curcas oil dielectric has the highest point, then it is possible to be developed being transformator insulation oil.
\end{abstract}

Keywords: dielectric of breakdown voltage, electrode, liquid insulation

\section{INTISARI}

Untuk memisahkan dua atau lebih penghantar listrik yang bertegangan dalam sistem tenaga listrik dibutuhkan suatu isolasi, sehingga antara penghantar-penghantar yang bertegangan tidak terjadi lompatan listrik atau percikan. Minyak merupakan bahan isolasi yang banyak digunakan untuk mengisolasi dan mendinginkan peralatan listrik tegangan tinggi. Isolator minyak merupakan isolasi cair yang sebagian besar berasal dari minyak bumi atau minyak mentah yang diolah secara khusus sehingga mempunyai sifat-sifat sebagai isolator, tetapi perkembangan dunia sekarang ini menuntut suatu produk yang aman dan ramah lingkungan untuk mengurangi efek pemanasan global. Keadaan ini membuka peluang penggunaan bahan energi terbarukan yang berasal dari minyak nabati. Pengujian tegangan tembus bahan isolasi cair minyak jarak pada berbagai konfigurasi elektroda dengan menggunakan minyak trafo gulf sebagai pembanding, bertujuan untuk mempelajari kekuatan isolasi minyak jarak terhadap tegangan tembus, dengan variasi temperatur dan jarak sela. Berdasarkan hasil pengujian menunjukkan bahwa tegangan tembus dielektrik minyak jarak mempunyai nilai yang tinggi, sehingga memungkinkan untuk dikembangkan menjadi minyak isolasi trafo.

Kata Kunci : elektroda, isolasi cair, tegangan tembus dielektrik

\section{PENDAHULUAN}

Isolasi sangat diperlukan yaitu untuk memisahkan dua atau lebih penghantar listrik yang bertegangan sehingga antara penghantarpenghantar tersebut tidak terjadi aliran, lompatan ataupun percikan listrik. Minyak merupakan bahan isolasi yang banyak digunakan untuk mengisolasi peralatan listrik tegangan tinggi karena dapat berfungsi sebagai pemisah antara bagian yang bertegangan dan juga sebagai pendingin. Isolasi dimaksudkan untuk memisahkan dua atau lebih penghantar listrik yang bertegangan, sehingga antara penghantarpenghantar yang bertegangan tidak terjadi lompatan listrik (flashover) atau percikan (sparkover). Pada tegangan yang semakin tinggi tentu diperlukan bahan isolasi yang mempunyai kuat isolasi yang lebih tinggi pula. Jika tegangan yang diterapkan pada penghantar telah mencapai nilai tertentu, maka bahan isolasi tersebut akan mengalami pelepasan muatan (lucutan, discharge), yang merupakan suatu bentuk kegagalan isolasi listrik. Kegagalan ini menyebabkan hilangnya kekuatan isolasi dan 
menyebabkan mengalirnya arus listrik dalam bahan isolasi tersebut.

Isolasi cair seperti minyak sebagian besar berasal dari minyak bumi atau minyak mentah yang diolah secara khusus sehingga mempunyai sifat-sifat sebagai isolator. Perkembangan dunia sekarang ini menuntut suatu produk yang aman dan ramah lingkungan guna mengurangi efek pemanasan global, sehingga perlu penggunaan bahan isolasi yang dapat terurai dengan tanah secara baik dan sedikit menimbulkan pencemaran, salah satunya dari bahan minyak organik. Kondisi ini semakin membuka peluang penggunaan bahan energi terbarukan, salah satunya dari bahan minyak nabati seperti minyak jarak, hal ini karena minyak jarak dapat terdegradasi secara biologis dengan sempurna dan relatif tidak mencemari tanah, udara dan air. Keadaan ini menarik perhatian peneliti untuk meneliti lebih lanjut mengenai kekuatan tegangan tembus minyak jarak sebagai salah satu dari karakteristik isolasi cair.

\section{A. Rumusan Masalah}

Berdasarkan permasalahan yang telah diuraikan pada latar belakang di atas, maka diperolah rumusan masalah untuk penelitian ini yaitu:

1. Bagaimanakah kekuatan tegangan tembus minyak jarak dibandingkan dengan minyak trafo gulf.

2. Bagimanakah pengaruh perubahan suhu dan jarak sela terhadap tegangan tembus minyak jarak dibandingkan dengan minyak trafo gulf.

\section{B. Tujuan Penelitian}

Tujuan dari Penelitian ini adalah :

1. Melakukan pengujian tegangan tembus terhadap kekuatan media isolasi cair pada minyak jarak dan membandingkan dengan minyak trafo gulf.

2. Melakukan pengujian pengaruh suhu dan jarak sela terhadap tegangan tembus pada minyak dan membandingkan dengan minyak trafo gulf.

\section{LANDASAN TEORI}

\section{A. Tinjauan Pustaka}

Penelitian dan pengujian mengenai tegangan tembus dielektrik telah banyak dilakukan oleh peneliti-peneliti terdahulu, baik mengenai kekuatan bahan isolasi maupun bentuk dari elektroda-elektrodanya. Penelitianpenelitian tersebut diantaranya adalah: Hasyim Asy'ari dan Jatmiko dengan penelitiannya tentang Pengaruh Perubahan Suhu Terhadap Tegangan Tembus pada Bahan Isolasi Cair. Alfian Junaidi (2008) yang meneliti mengenai pengaruh perubahan suhu terhadap tegangan tembus pada bahan isolasi cair; Samuel Panggabean (2008) yang meneliti tentang pengaruh perubahan suhu terhadap kekuatan dielektrik berbagai minyak isolasi transformator.

\section{B. Teori Kegagalan Isolasi Cair}

Apabila suatu tegangan dikenakan terhadap dua elektroda yang dicelupkan kedalam cairan isolasi maka terlihat adanya konduksi arus yang kecil. Jika tegangan dinaikkan secara kontinyu maka pada titik kritis tertentu akan terjadi lucutan diantara ke dua elektroda. Teori kegagalan isolasi cair dapat digolongkan dalam empat jenis sebagai berikut:

1. Teori kegagalan zat murni atau elektronik

Menganggap proses kegagalan dalam zat cair serupa dengan yang terjadi dalam gas, sehingga diperlukan elektron awal yang akan memulai proses kegagalan.

2. Teori kegagalan gelembung gas

Kegagalan ini disebabkan oleh adanya gelembung-gelembung gas di dalam isolasi cair yang bisa terbentuk diantaranya karena permukaan elektroda tidak rata, sehingga terdapat kantong-kantong udara pada permukaannya, sehingga muncul produk-produk baru berupa gelembung gas yang saling sambung-menyambung membentuk jembatan yang akan mengawali terjadinya kegagalan.

3. Teori kegagalan bola cair Air dan uap

Air terdapat pada minyak, terutama pada minyak yang telah lama digunakan. Jika terdapat medan listrik, maka molekul uap air terpolarisasi membentuk suatu dipol yang akan akan tersusun semacam jembatan bertahanan lebih rendah dibanding isolasi cair itu sendiri sehingga terbentuk suatu kanal peluahan memanjang sampai menghasilkan tembusan listrik.

4. Teori kegagalan tak murni

Antara padat partikel debu atau serat selulosa yang ada seringkali ikut tercampur dengan minyak. Pada saat diberi medan listrik, partikel-partikel ini akan terpolarisasi dan 29 
membentuk jembatan yang menyebabkan terjadinya kegagalan.

\section{Fungsi Minyak Isolasi}

Minyak isolasi secara umum digunakan pada peralatan tegangan tinggi yang berfungsi sebagai bahan dielektrik, bahan pendingin dan bahan pemadam busur api. Berikut ini akan dijelaskan penggunaan minyak isolasi pada beberapa peralatan tegangan tinggi antara lain:

a. Transformator daya

Transformator memerlukan minyak isolasi sebagai bahan pengisolasian bagian-bagian dari transformator seperti isolasi antar belitan, belitan dengan inti dan belitan dengan badan (casing) transformator. Di samping itu juga, minyak isolasi berfungsi sebagai bahan pendingin atau menyalurkan panas ke sirip-sirip transformator serta sebagai pemadam busur api apabila terjadi percikan-percikan dalam belitan transformator.

\section{b. Kapasitor Daya}

Penggunaan minyak isolasi pada kapasitor berfungsi sebagai bahan dielektrik, sebagai pendingin dan sebagai pencegah terjadinya rongga udara di antara elektroda kapasitor. Sifat-sifat yang harus dimiliki minyak isolasi pada suatu kapasitor adalah faktor daya dielektrik yang rendah, viskositas yang rendah dan sifat penyalaan yang rendah.

c. Kabel Daya

Penggunaan minyak isolasi pada kabel daya adalah sebagai bahan isolasi antara perisai konduktornya dengan isolasi terluarnya. Minyak isolasi juga berfungsi sebagai bahan pendingin pada kabel daya. Sifat-sifat yang harus dimiliki isolasi pada kabel daya adalah viskositas minyak isolasi harus sangat rendah, tahanan isolasi tinggi, koefisien muai yang rendah dan tidak bereaksi dengan asam atau alkali pada suhu kerja serta bebas dari kandungan gas.

d. Pemutus Tenaga (Circuit Breaker)

Minyak isolasi pada pemutus tenaga berfungsi sebagai pemadam busur api tersebut. Sifat-sifat yang harus dimiliki minyak isolasi pada peralatan pemutus tenaga adalah sifat penyalaan yang rendah dan tidak menimbulkan perkaratan pada peralatan.
6. Jenis-Jenis Minyak Isolasi

Minyak isolasi terdiri dari bebrapa jenis, baik dari segi pembuatanya maupun dari jenis bahannya. Pembagian dari jenis minyak isolasi ditentukan berdasarkan bahan dan cara pembuatanya. Pada saat ini minyak isolasi yang sering digunakan adalah :

a. Minyak Isolasi Mineral

Minyak isolasi mineral diketahui berisi berbagai jenis molekul dan secara luas dapat digolongkan kedalam jenis yang mengandung malam (paraffin) dengan rumus kimianya $\mathrm{CnH} 2 \mathrm{n}+2$, naphthenic $(\mathrm{CnH} 2 n)$, aromatis $(\mathrm{CnHn})$ atau kelompok molekul tingkat menengah lainnya

b. Minyak Isolasi Sintesis

Minyak Isolasi sintesis merupakan minyak isolasi hasil pengembangan pada bidang industri kimia. Kelebihan utamanya adalah bersifat tidak mudah terbakar. Pada isolasi mineral masih mengalami keterbatasanketerbatasan, karena sifatnya yang mudah beroksidasi dengan udara, mengalami pemburukan yang cepat dan sifat kimianya dapat berubah akibat kenaikan temperatur yang terjadi akibat pemadaman busur api atau berhentinya peralatan beroperasi.

c. Minyak Organik

Minyak organik dapat terdegradasi secara biologis dengan sempurna dan relatif tidak mencemari tanah, udara dan air. Selain itu minyak organik persediaanya melimpah dan kecil kemungkinannya untuk habis kelompok minyak organik meliputi minyak sayur, minyak damar, dan ester.

\section{METODE PENELITIAN}

\section{A. Materi Penelitian}

1. Melakukan pengujian tegangan tembus dielektrik minyak jarak mengunakan elektroda bidang-jarum dengan variasi perubahan jarak sela

2. Melakukan pengujian tegangan tembus dielektrik minyak jarak mengunakan konfigurasi elektroda bidang-jarum dengan variasi perubahan temperatur.

\section{B. Bahan Penelitian}

Bahan yang digunakan pada penelitian ini adalah minyak jarak. 


\section{Alat penelitian}

Alat-alat yang digunakan pada penelitian ini adalah sebagai berikut:

1. Kit Pembangkit Tegangan

Kit pembangkit tegangan terdiri dari trafo ukur, resistor, tongkat pentanahan, sangkar tupai dan panel kontrol .

2. Kotak Pengujian

Kotak ini digunakan sebagai tempat pengujian minyak sawit dan minyak trafo berukuran $20 \times 15 \times 15 \mathrm{~cm}$ dan terbuat dari acrylic.

3. Elemen Pemanas dan termometer

Elemen pemanas ini berfungsi untuk menaikan temperatur minyak yang akan di uji, temperatur ini diukur menggunakan termometer.

4. Elektroda dan kabel penghubung

Elektroda yang digunakan dalam penelitian terbuat dari bahan aluminium, dengan bentuk elektroda bidang, bola-jarum.

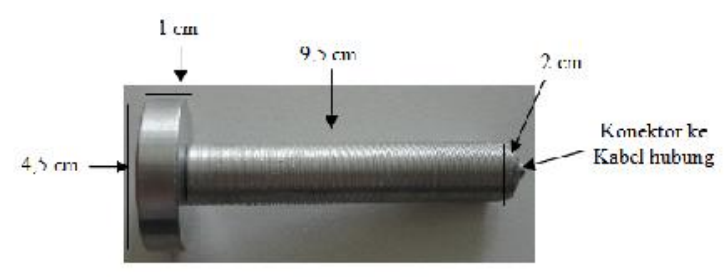

Gambar 1. Elektroda Bidang

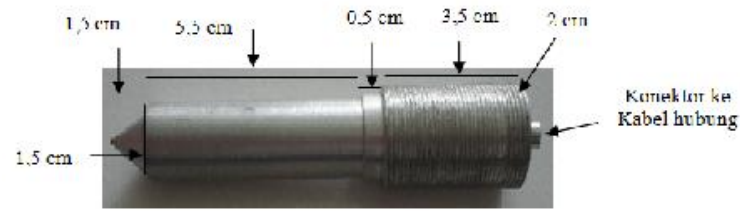

Gambar 2. Elektroda Jarum

\section{Langkah Penelitian}

Dasar yang digunakan dalam proses pengambilan data, yaitu mengacu pada standar IEC 156 tentang pengujian tegangan tembus minyak isolasi. Standar pengujian tersebut yaitu:

1. Persiapan Sampling

Sesegera mungkin sebelum mengisi kotak uji, sampling harus dikocok berulang kali secara lembut untuk memastikan adanya homogenisasi kontaminan cairan tanpa menimbulkan gelembung udara pada cairan.

2. Pengisian Kotak Uji

Sebelum melaksanakan pengujian, bersihkan kotak uji, dinding-dindingnya, elektroda dan komponen lainnya. Kemudian tuang kedalam kotak uji secara perlahan dan hindari terjadinya gelembung-gelembung udara yang muncul pada minyak.

3. Pemberian Tegangan

Berikan tegangan pada elektroda dengan kenaikan yang seragam (konstan) dimulai dari $0 \mathrm{~V}$ sampai sekitar $2,0 \mathrm{kV} / \mathrm{dt} \pm 0.2$ $\mathrm{kV} / \mathrm{dt}$ sampai timbul tegangan tembus.

4. Laporan

Data yang dimasukkan dalam laporan adalah hasil dari nilai rata-rata dari 6 kali percobaan yang sudah dilakukan. Data-data ini bisa ditampilkan dalam bentuk tabel.

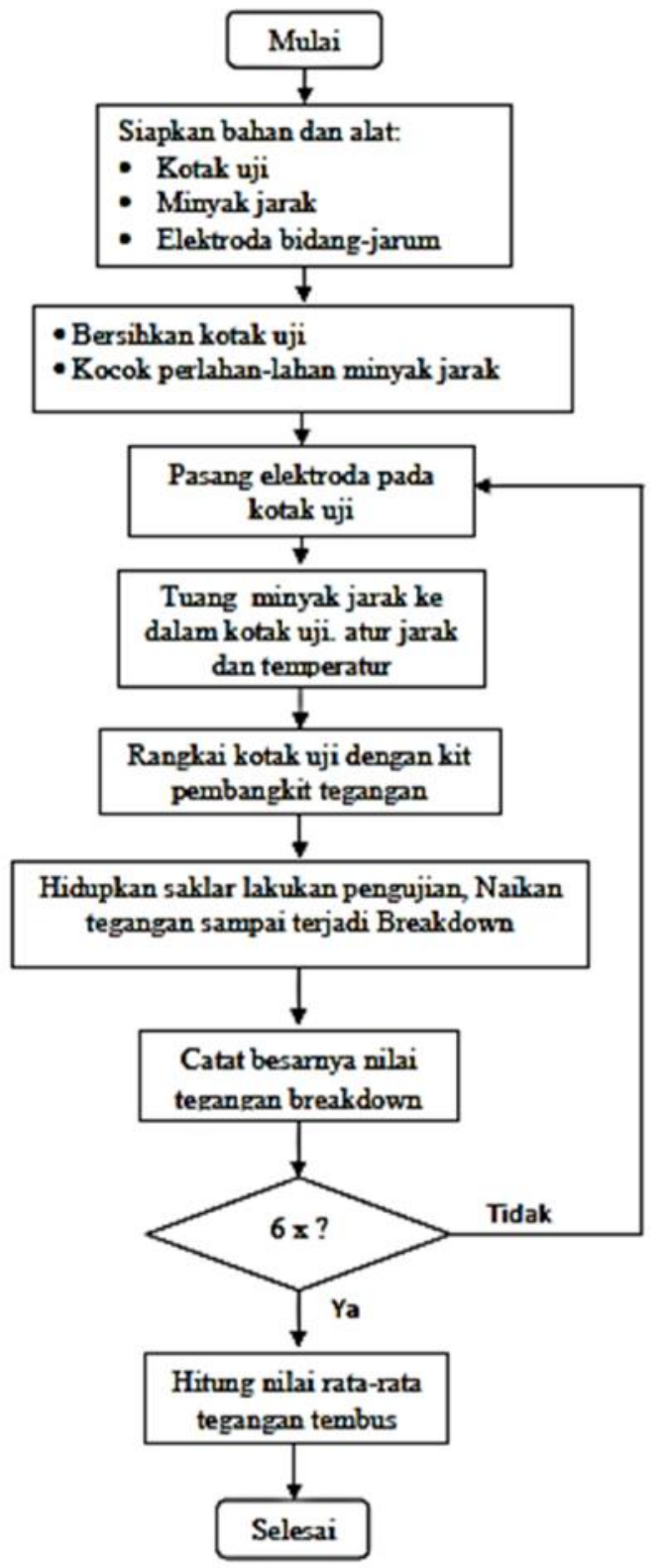

Gambar 3. Diagram Alir Proses Pengujian Minyak Jarak 


\section{HASIL DAN PEMBAHASAN}

A. Hasil Penelitian dan Pembahasan Minyak Jarak

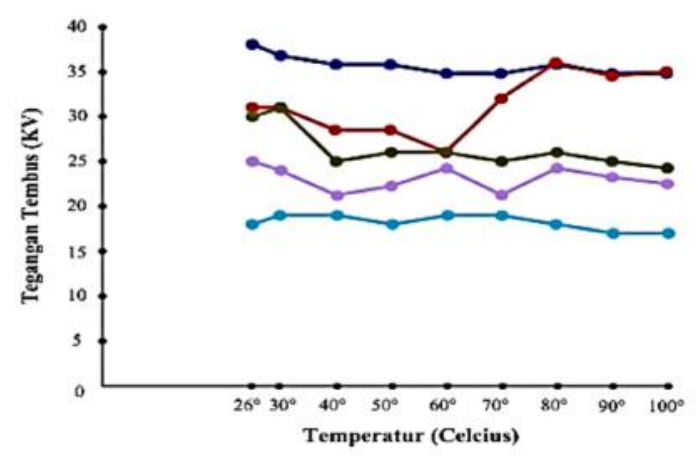

- Sela 7,5 mm $y=0,070 x^{2}-1,020 x+38,76$ $R^{2}=0,848$

- Sela $5,0 \mathrm{~mm} \quad \mathrm{y}=0,271 \mathrm{x}^{2}-1,966 \mathrm{x}+32,45$ $\mathrm{R}^{2}=0,603$

- Scla $3,5 \mathrm{~mm} \quad \mathrm{y}=0,118 \mathrm{x}^{2}-1,863 \mathrm{x}+32,02$ $R^{2}=0,698$

- Sela 2,5 mm $y=0,080 x^{2}-0,967 x+25,19$ $\mathrm{R}^{2}=0,215$

- Sela 1,5 mm $y=-0,079 x^{2}+0,606 x+17,69$ $\mathrm{R}^{2}=0,709$

Gambar 4. Grafik Tegangan Tembus Minyak Jarak pada Elektroda Bidang-Jarum

Dari Tabel 4, hasil Multiple Regression diperoleh persamaan sebagai berikut:

$$
\text { Ln } Y=2,863+0,108 X_{1}-0,001 X_{2}
$$

dimana:

$\mathrm{X}_{1}=$ jarak sela

$\mathrm{X}_{2}=$ suhu

Pada saat belum ada pengaruh suhu dan jarak sela maka nilai tegangan tembus sebesar 2,863 $\mathrm{kV}$ dengan setiap kenaikan jarak sela $1 \mathrm{~mm}$ akan diikuti peningkatan tegangan tembus sebesar 0,108 kalinya dan setiap kenaikan suhu $1^{\circ} \mathrm{C}$ akan diikuti penurunan tegangan tembus sebesar 0,001 kalinya.

\section{B. Hasil Penelitian dan Pembahasan Minyak Trafo Gulf}

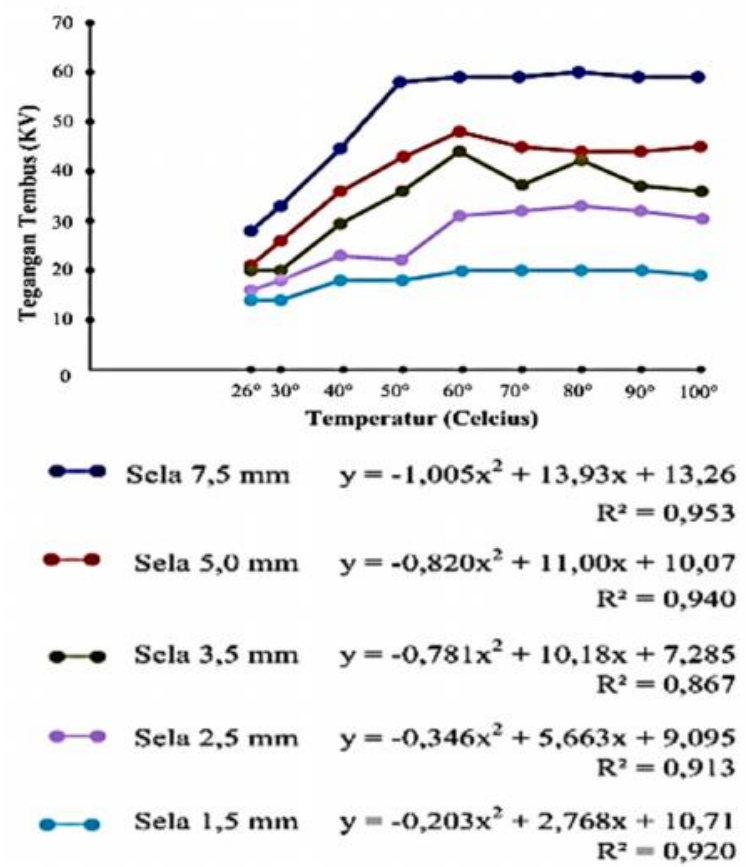

Gambar 5. Grafik Tegangan Tembus Isolasi Minyak Trafo Gulf Pada Elektroda Bidang-Jarum

Dari Tabel 5, hasil Multiple Regression diperoleh persamaan sebagai berikut:

$$
\text { Ln } \mathrm{Y}=2,317+0,157 \mathrm{X}_{1}+0,008 \mathrm{X}_{2}
$$

dimana:

$\mathrm{X}_{1}=$ jarak sela

$\mathrm{X}_{2}=$ suhu

Pada saat belum ada pengaruh suhu dan jarak sela maka nilai tegangan tembus sebesar 2,317 kV dengan setiap kenaikan jarak sela $1 \mathrm{~mm}$ akan diikuti peningkatan tegangan tembus sebesar 0,157 kalinya dan setiap kenaikan suhu $1^{\circ} \mathrm{C}$ akan diikuti peningkatan tegangan tembus sebesar 0,008 kalinya. 
C. Perbandingan Karakteristik Tegangan Tembus Minyak Jarak dan Minyak Trafo Gulf Pada Konfigurasi Elektroda BidangJarum

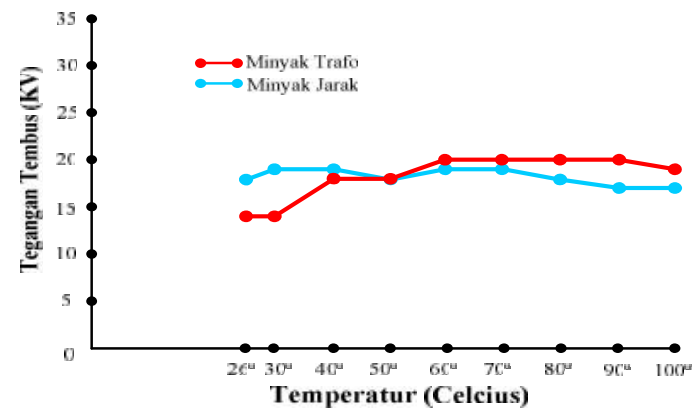

(a)

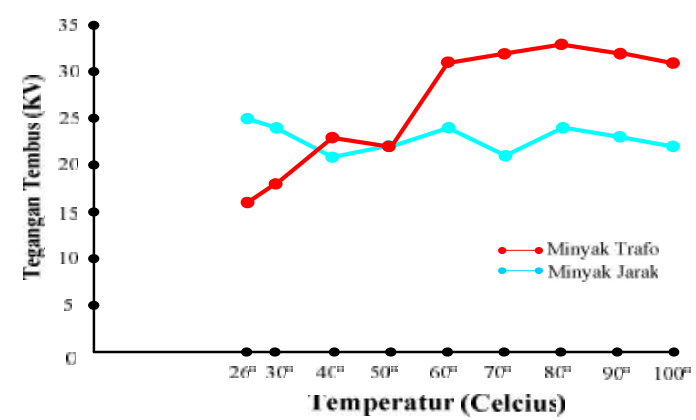

(b)

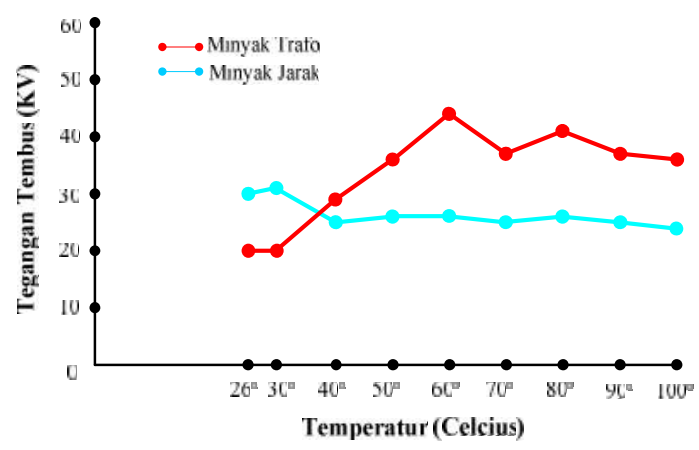

(c)

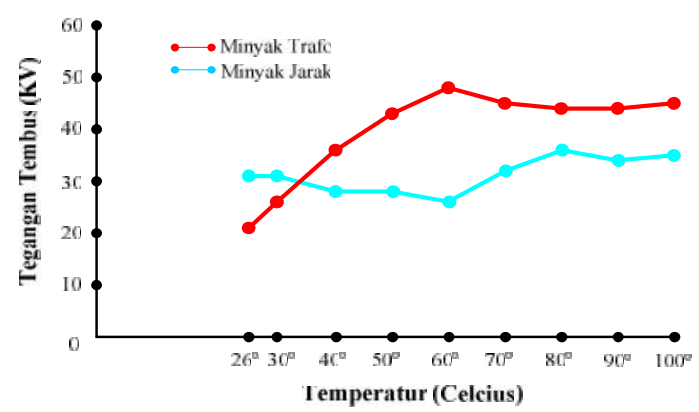

(d)

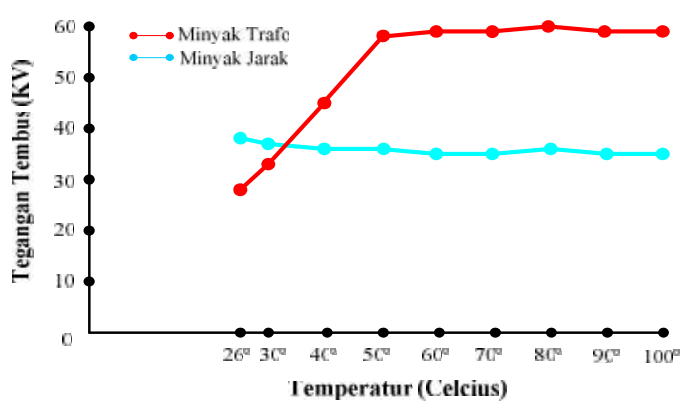

(e)

Gambar 6. Karakteristik Tegangan Tembus Minyak Jarak dan Minyak Gulf : Konfigurasi Elektroda Bidang-Jarum (a) Jarak sela 1,5 mm; (b) Jarak sela 2,5 mm; (c) Jarak sela 3,5 mm; (d) Jarak sela 5,0 $\mathrm{mm}$; (e) Jarak sela 7,5 mm

Dengan menggunakan program SPSS. 19 Compare Means Independent Sample Test diperoleh hasil perbandingan tegangan tembus minyak jarak dan minyak gulf pada konfigurasi elektroda bidang-jarum yaitu :

1. Pada jarak sela 1,5 dan $2,5 \mathrm{~mm}$ rata-rata tegangan tembus minyak jarak dan minyak gulf sama, yaitu sebesar 18,2222 kV untuk sela 1,5 mm dan $22,8889 \mathrm{kV}$ untuk sela 2,5 $\mathrm{mm}$.

2. Pada jarak sela $3,5 \mathrm{~mm}$ tegangan tembus minyak gulf lebih baik dari pada minyak jarak dengan rata-rata tegangan tembus minyak jarak adalah $26,4444 \mathrm{kV}$ sedangkan tegangan tembus minyak gulf adalah $33,4444 \mathrm{kV}$.

3. Pada jarak sela $5 \mathrm{~mm}$ tegangan tembus minyak gulf lebih baik dari pada minyak jarak dengan rata-rata tegangan tembus minyak jarak adalah $31,2222 \mathrm{kV}$ sedangkan tegangan tembus minyak gulf adalah $39,1111 \mathrm{kV}$.

4. Pada jarak sela $2,5 \mathrm{~mm}$ tegangan tembus minyak gulf lebih baik dari pada minyak jarak dengan rata-rata tegangan tembus minyak jarak adalah $35,8889 \mathrm{kV}$ sedangkan tegangan tembus minyak gulf adalah $51,1111 \mathrm{kV}$.

\section{KESIMPULAN}

\section{A. Kesimpulan}

Berdasarkan hasil pengujian dapat diambil kesimpulan bahwa terjadi perbedaan 
nilai tegangan tembus dielektrik minyak jarak dan minyak trafo gulf pada konfigurasi elektroda bidang-jarum seiring perubahan sela dan temperatur, perbedaan tersebut yaitu:

1. Tegangan tembus minyak jarak pada konfigurasi elektroda bidang-jarum pada saat belum ada pengaruh suhu dan jarak sela sebesar 2,317 $\mathrm{kV}$ dengan setiap kenaikan jarak sela $1 \mathrm{~mm}$ akan diikuti peningkatan tegangan tembus sebesar 0,157 kalinya dan setiap kenaikan suhu $1^{\circ} \mathrm{C}$ akan diikuti peningkatan tegangan tembus sebesar 0,008 kalinya.

2. Tegangan tembus minyak jarak pada konfigurasi elektroda bidang-jarum pada saat belum ada pengaruh suhu dan jarak sela sebesar 2,317 $\mathrm{kV}$ dengan setiap kenaikan jarak sela $1 \mathrm{~mm}$ akan diikuti peningkatan tegangan tembus sebesar 0,157 kalinya dan setiap kenaikan suhu $1{ }^{\circ} \mathrm{C}$ akan diikuti peningkatan tegangan tembus sebesar 0,008 kalinya.

3. Hasil perbandingan tegangan tembus minyak jarak dan minyak trafo gulf pada konfigurasi elektroda bidang-jarum yaitu :

a. Pada jarak sela 1,5 dan 2,5 mm rata-rata tegangan tembus minyak jarak dan minyak gulf sama, yaitu sebesar $18,2222 \mathrm{kV}$ untuk sela $1,5 \mathrm{~mm}$ dan $22,8889 \mathrm{kV}$ untuk sela $2,5 \mathrm{~mm}$.

b. Pada jarak sela $3,5 \mathrm{~mm}$ tegangan tembus minyak gulf lebih baik dari pada minyak jarak dengan rata-rata tegangan tembus minyak jarak adalah 26,4444 $\mathrm{kV}$ sedangkan tegangan tembus minyak gulf adalah $33,4444 \mathrm{kV}$.

c. Pada jarak sela $5 \mathrm{~mm}$ tegangan tembus minyak gulf lebih baik dari pada minyak jarak dengan rata-rata tegangan tembus minyak jarak adalah 31,2222 $\mathrm{kV}$ sedangkan tegangan tembus minyak gulf adalah $39,1111 \mathrm{kV}$.

d. Pada jarak sela $2,5 \mathrm{~mm}$ tegangan tembus minyak gulf lebih baik dari pada minyak jarak dengan rata-rata tegangan tembus minyak jarak adalah $35,8889 \mathrm{kV}$ sedangkan tegangan tembus minyak gulf adalah $51,1111 \mathrm{kV}$.

\section{B. Saran}

Saran yang dapat disampaiakan oleh peneliti kepada pembaca ataupun kepada para peneliti-peneliti yang akan melakukan penelitian tentang kuat tegangan tembus pada isolasi cair khususnya tentang energi terbarukan seperti pemanfaatan minyak jarak ini yaitu:

1. Dalam penaikan temperatur perlu menggunakan sistem otomatis, sehingga peneliti tidak perlu mengawasi temperatur terus-menerus.

2. Jika ingin melanjutkan penelitian ini disarankan agar lebih memfokuskan karakteristik fisika dan kimia dari minyak jarak seperti viskositas dan titik tuang sebelum dilakukan pengujian tegangan tembus.

\section{DAFTAR PUSTAKA}

[1] Verweij, J. F. and Klootwijk, J. H. (1996). Dielectric Breakdown I : A Review Of Oxide Breakdown. Microelectronics Journal, Volume 27, Issue 7, October 1996, Pages 611-622.

[2] Tobing, B. L. (2003). Dasar Teknik Pengujian Tegangan Tinggi. Gramedia Pustaka Utama, Jakarta.

[3] Syakur, A. dan Facta, M. (2005). Perbandingan Tegangan Tembus Media Isolasi Udara dan Media Isolasi Minyak Trafo Menggunakan Elektroda BidangBidang. Teknik Elektro, Universitas Diponegoro.

[4] Naidu, M. S. et.al. (1995). High Voltage Engeneenering, 2ed. Tata McGraw-Hill Publising Company Limited, New Delhi.

[5] Arismunandar, A. (1983). Teknik Tegangan Tinggi : Suplemen. Ghalia Indonesia, Jakarta.

[6] Hambali, E. dkk. (2007). Jarak Pagar Tanaman Penghasil Biodisel. Penebar Swadaya, Jakarta.

[7] Hardaniari, Y. E. Y. (2008). Karakteristik Minyak Jarak Pagar (Crude Jatropha Oil) Hasil Pengepresan Biji dengan Variasi Kematangan Buah yang Dibudidayakan Di Kab. Kupang. UGM, Yogyakarta. 
[8] Bata, S. (2008). Optimasi Ektrasi dan Penghilangan Gum Minyak Jarak Pagar (Jatropha Curcas Linn) Serta Karakterisasinya Sebagai Biofuel. UGM, Yogyakarta.

[9] Nugroho, A. (2006). Biodiesel Jarak Pagar, Bahan Bakar Alternatif yang Ramah Lingkungan. PT Agro Media. Tangerang.

[10] Panggabean, S. (2008). Pengaruh Suhu Terhaddap Kekuatan Dielektrik Berbagai Minyak Isolasi Transformator ( Gulf, Nynas, shell Diala B dan Total). Medan.

[11] Kristiningsih, S. (2002). Pengaruh Suhu Terhadap Kinerja Material Isolasi Komposit Resin Epoksi-Fiber Glass. UGM, Yogyakarta.

[12] Alhusin, M. S. S. (2003). Aplikasi Statistik Praktis dengan SPSS.10 ed. 2. Graha Ilmu, Yogyakarta.

[13] IEC 60156. (1995). Insulating liquidsDetermination of the breakdown voltage at power frequency-Test method : second edition. IEC, IEEE. 